\title{
EFFECT OF DIFFERENT LEVELS OF OPTIZYME AND PHYTAS E ENZYMES AND THEIR INTERACTIONS ON THE PERFORMANCE OF BROILER CHICKENS FED CORN/SOYBEAN MEAL: 2. TIBIA CHARACTERISTICS AND CALCIUM AND PHOSPHORUS RETENTION EFFICIENCY
}

\author{
M. A. Metwally ${ }^{1}$, M. F. A. Farghly ${ }^{1}$, Z. S. H. Ismail ${ }^{2}$, M.E. Ghonime ${ }^{3}$ and \\ Inas A. Mohamed ${ }^{4}$
}

${ }^{1}$ Dept. of poultry Production, Fac. Of Agric., Univ. of Assiut, Egypt, 71526

${ }^{2}$ Dept.Animal production, Fac. of Agri., South Valley Univ., Egypt.

${ }^{3}$ Dept. of Animal and Poultry Production, Fac. of Agri., and Natural Resources, Aswan Univ., Egypt.

${ }^{4}$ Dept. of poultry Production, Fac. Of Agric., Univ. of Beni Suef University, Egypt.

(Received 13/1/2020, accepted 25/2/2020)

\section{SUMMARRY}

\begin{abstract}
A total of 180 unsexed 1-day old IR broiler chicks were randomly distributed into 6 treatments of 3 replicates each ( 10 birds each) in experiment for 5 weeks of age. A factorial design $(3 \times 2)$ was used in which there were three levels of multienzymes, optizyme $(0,250,500 \mathrm{mg} / \mathrm{kg}$ diet $)$ and two levels of phytase enzyme $(0,1500 \mathrm{FTU} / \mathrm{kg}$ diet $)$. The results showed that broiler chicks fed on either 250 or $500 \mathrm{mg} / \mathrm{kg}$ diet of optizyme alone or plus $1500 \mathrm{FTU} / \mathrm{kg}$ diet had significantly improved body weight gain (BWG) compared to control group. Tibia ash and phosphorous percentages were increased significantly $(\mathrm{P}<0.05)$ in broilers fed diets contained $250 \mathrm{mg} / \mathrm{kg}$ diet optizyme. Phosphorus retention efficiency percentages were increased significantly $(\mathrm{P}<0.05)$ in broilers fed diets contained $250 \mathrm{mg} / \mathrm{kg}$ diet optizyme alone or $250 \mathrm{mg} / \mathrm{kg}$ diet optizyme plus $1500 \mathrm{FTU} / \mathrm{kg}$ diet phytase. It could be concluded that the level of 250 or $500 \mathrm{mg} / \mathrm{kg}$ diet optizyme and $1500 \mathrm{FTU} / \mathrm{kg}$ diet phytase is effective for increasing absorption and bioavailability of phosphorus, which could decrease excretion of phosphorous and, therefore, environmental pollution. In addition, feeding broilers with these treated feeds might improve body weight gain.
\end{abstract}

Keywords: Performance response, tibia, calcium and phosphorus retention efficiency and broiler chickens.

\section{INTRODUCTION}

Poultry industry is becoming increasingly receptive to the use of exogenous enzymes supplementation. Enzyme supplementation to the poultry rations has a positive effect on feeds digestibility and leads to better productivity and performance.

Numerous studies have shown that supplementation of exogenous enzymes in wheat, barley, sorghum or triticale-based rations can improve performance of poultry to a level compared to that obtained by cornsoya-based rations. Naturally, the gastrointestinal tract of poultry produces enzymes to aid the digestion of nutrients (Abd El-Hack et al., 2017).

Nowadays, phytase is utilized extensively to improve animal feeds utilization and economic of livestock farming due to many potential, such as overcome anti-nutritional factors such as phytic acid, improve digestion, and gut ecology and thus enhancing the use of nutrients for meat and egg production, reduce environmental pollution and increase profits due to nutrient equivalency value (Enshasy et al. 2018 and Attia et al. 2020). Phytase mainly improved phytate phosphorus utilization, particularly of high phytic acids diets 
and enhanced the use of protein/amino acids, energy, phosphorous calcium and several trace minerals (Enshasy et al., 2018)

However, the birds do not have enough enzymes to digest adequate fiber and need some commercial exogenous enzymes in the diets to improve the digestion. Enzyme is a biological catalyst composed of proteins, amino acids with minerals and vitamins.

The advantages of using commercial enzymes in poultry feeds include improved productive performance and feed utilization, minimized environmental pollution due to reduced nutrient of manure. Therefore, the objective of the present study was to investigate effect of exogenous enzymes on Performance response, tibia characteristics, and calcium and phosphorus retention efficiency.

\section{MATERIALS AND METHODS}

The present study was carried out at the Poultry Research Farm, Poultry Production Dept., Faculty of Agriculture, South Valley University, Qena. EGYPT.

\section{Management and experimental design:}

A total of 180 (IR) broiler chicks (one day old) were randomly divided into 6 treatments. Each treatment was divided into 3 replicates of 10 each. The birds were reared at $34^{\circ} \mathrm{C}$ temperature as standard brooding temperature and then, gradually reduced to reach $24^{\circ} \mathrm{C}$ at the end of the experiment. A light schedule used was $23 \mathrm{~h}$ of light during the entire period of the experiment, and the level of relative humidity ranged from 55 to $60 \%$. The enzyme was supplemented in addition to the diet and was not included in the nutrient matrix. Birds were fed on starting commercial diet (Table 1) containing (23\% crude protein, ME, $3000 \mathrm{Kcal}$. / Kg)

Table (1): Feed ingredients and chemical analyses of basal diets:

\begin{tabular}{|c|c|c|}
\hline Ingredients, $\%$ & $\begin{array}{c}0-2 \text { weeks } \\
\text { Starter }\end{array}$ & $\begin{array}{c}3-5 \text { weeks } \\
\text { Grower }\end{array}$ \\
\hline Corn (grains) & 54.00 & 59.20 \\
\hline Soybean Meal (44\%) & 32.85 & 28.00 \\
\hline Corn Gluten Meal (62\%) & 6.50 & 6.00 \\
\hline Soybean Oil & 2.70 & 2.50 \\
\hline Di-Calcium Phosphate & 1.46 & 1.52 \\
\hline Limestone & 1.51 & 1.80 \\
\hline Premix & 0.30 & 0.30 \\
\hline Salt $(\mathrm{NaCl})$ & 0.30 & 0.30 \\
\hline DL-Methionine & 0.28 & 0.28 \\
\hline L-Lysine HCL & 0.10 & 0.10 \\
\hline Total & 100 & 100 \\
\hline \multicolumn{3}{|c|}{ Chemical analysis (Calculated) } \\
\hline Crude Protein \% & 23.18 & 21.20 \\
\hline $\mathrm{ME} \mathrm{Kcal/} \mathrm{Kg} \mathrm{diet}$ & 3009 & 3040 \\
\hline Calcium $\%$ & 1.10 & 0.93 \\
\hline Available Phosphorus \% & 0.42 & 0.42 \\
\hline Lysine \% & 1.19 & 1.07 \\
\hline Methionine \& Cysteine \% & 1.06 & 1.01 \\
\hline
\end{tabular}

Each 3 Kg of premix contains: Vitamins: A: 12000000 IU; D3 2000000 IU; E: 10000 mg; K3: 2000 mg; B1:1000 mg; B2: $5000 \mathrm{mg}$; B6:1500 mg; B12: $10 \mathrm{mg}$; Biotin: $50 \mathrm{mg}$; Choline chloride: $250000 \mathrm{mg}$; Pantothenic acid: $10000 \mathrm{mg}$; Nicotinic acid: 30000 mg; Folic acid: 1000 mg; Minerals: Mn: 60000 mg; Zn: 50000 mg; Fe: 30000 mg; Cu: 10000 $\mathrm{mg}$; I: $1000 \mathrm{mg}$; $\mathrm{Se}: 100 \mathrm{mg}$ and Co: $100 \mathrm{mg}$. 
from one day old to2weeks of age and growing commercial diet containing (21\% crude protein, ME, 3000 Kcal. $/ \mathrm{Kg}$ ) from 3 to 5 weeks of age(marketing), diets were formulated according to the Nutrient Recommendations for poultry (NRC, 1994).

\section{Experimental design:}

The chickens were fed three levels of Optizyme enzyme $(0,250$ and $500 \mathrm{mg} / \mathrm{kg}$ diet and two levels of Phytase enzyme supplementation ( 0 and 1500 FTU/kg diet). One FTU of Phytase enzyme activity (FTU) is defined as the activity of $0.030 \mu \mathrm{g}$ of Phytase. Optizyme is a commercial multienzyme consist of multienzymes product containing proteases, amyloglucosidase, xylanase, $\beta$-glucanase, cellulases and hemicellulases, (Product of Optivite International LTD). One unit (FTU) is equal to the enzyme activity that liberates $1 \mu \mathrm{mol}$ or tho-phosphate from $5.1 \mathrm{mmol}$ of sodium phytin per minute at $37^{\circ} \mathrm{C}$ and $\mathrm{pH}$ 5.5.) ( Marketed by BASF, Germany). The experimental treatments were as follows: T1 $(0 \mathrm{mg} / \mathrm{kg}$ diet optizyme and 0 FTU/kg diet phytase); T2 (0 mg/kg diet optizyme and $1500 \mathrm{FTU} / \mathrm{kg}$ diet phytase); T3 (250 mg/kg diet optizyme and 0 FTU/kg diet phytase); T4 (250 mg/kg diet optizyme and $1500 \mathrm{FTU} / \mathrm{kg}$ diet phytase); T5 (500 mg/kg diet optizyme and 0 FTU/kg diet phytase); T6 $(500 \mathrm{mg} / \mathrm{kg}$ diet optizyme and $1500 \mathrm{FTU} / \mathrm{kg}$ diet phytase).

Broilers in each replicate were weighed $(\mathrm{g})$ as a group replicate and feed consumption was also weighed weekly till 5 wks of age. Body weight gain (BWG) (g/chick) and feed conversion (FCR, g feed/g gain) were calculated from one day old to marketing age.

At 35 days of age, a random sample of 3 growing birds from each replicate were slaughtered after $8 \mathrm{~h}$ fasting according to the Islamic method using a sharp knife and cutting into the jugular vein, carotid artery and windpipe, processed. Left tibia was removed and cleaned from adhering flesh, dried under $110 \mathrm{C}$ for 12 $\mathrm{hr}$, left to cool, weighed and then calculated as relative to live body weight. Tibia diameters were measured using a caliper. According to Rezaeipour et al., (2014) the (WLI) weight/length index was calculated by dividing bone weight (in $\mathrm{mg}$ ) by its length (in $\mathrm{mm}$ ). In order to determine the minerals concentrations, the tibiae were kept frozen in plastic bags at $-20^{\circ} \mathrm{C}$ to maintain wetness until analysis. Then, frozen tibiae were thawed by leaving them in plastic bags at room temperature for $1 \mathrm{~h}$ and oven-dried at $105^{\circ} \mathrm{C}$ for $12 \mathrm{~h}$. Subsequently, samples were then grinded in a mill, weighed and put in a muffle furnace overnight at $550^{\circ} \mathrm{C}$ for $3 \mathrm{~h}$. The ash was used to quantify calcium and phosphorous amount in the tibia. The calcium and phosphorous contents (\% of ash) were measured by atomic absorption and spectrophotometer methods, respectively. Tibia ash was determined according to AOAC (1990).

To determine calcium and phosphorus retention efficiency $\%$, a separate experiment during the period from 36 to 38 days of age (for 3 days) was carried out, the three replicates from each treatment were set for total collection method. Chicks were fed on their corresponding experimental diets for $72 \mathrm{~h}$, in which feed consumption and excreta voided, were accurately determined. The excreta was collected for each replicate, cleaned from feathers and feed then weighed, dried in a forced air oven at $70^{\circ} \mathrm{C}$ for $36 \mathrm{~h}$. Samples were then finally ground and placed in screw-top glass jars until analyses. Calcium and phosphorus in feed and excreta were measured by methods of AOAC (1990).The percentage of calcium and phosphorus efficiency was determined based on its retention (Graña et al. (2013) in broiler chickens fed corn/soybean meal.

Calcium and phosphorus retention (g/bird) was calculated as nutrient intake (g/bird) minus nutrient excretion ( $\mathrm{g} / \mathrm{bird})$. Nutrient retention $(\%)$ indicates the percentage of nutrient retained by the bird as a function of nutrient intake, and it was calculated as follows:

$$
\text { Nutrient retention }(\%)=\frac{\text { nutrient retention }(\mathrm{g} / \mathrm{bird})}{\text { nutrient intake }(\mathrm{g} / \mathrm{bird}} \times 100
$$

\section{Statistical analysis:}

The data were statistically analyzed by factorial design ( $3 \times 2)$, three levels of optizymes and two levels of phytase enzymes using ANOVA and General Linear Models (GLM) Procedure of SAS software (SAS, 2009). Duncan'smultiple range tests (Duncan 1955) was used to determine differences among means when treatment effects were significant. Significant differences were considered to exist when $(\mathrm{P}<0.05)$.

The mathematical model was as follows:

$$
Y i j k=\mu+O i+P j+(O V) i j+E i j k
$$




\section{Metwally et al.}

Where: Yijk $=$ any observation; $\mu=$ the population mean. Oi= optizyme levels effect $(\mathrm{i}=1,2$ and 3$)$; $\mathrm{Pj}=$ Phytase levels effect $(\mathrm{j}=1$ and 2$) ;(\mathrm{OP}) \mathrm{ij}=$ Interaction of optizyme levels $\times$ phytase levels. Eijk= Experimental error.

\section{RESULTS AND DISCUSSIONS}

\section{Performance response:}

The results of body weight response (body weight, BW., body weight gain, BWG., feed intake, FI and feed conversion ratio ,FCR ) as affected by treatments at 5 weeks of age are presented in Table (2). BWG for birds fed either 250 or $500 \mathrm{mg} / \mathrm{kg}$ diet optizyme enzyme had a significantly $(\mathrm{P} \leq 0.05)$ higher BWG than control group. The obtained results are in agreement with Kalantar et al. (2015) and Zeng et al. (2015) who mentioned that enzyme supplemented wheat and barley diets with multienzymes to significant $(\mathrm{P}<0.05)$ increased BW gain compared to without enzymes. Supplementation with multi-enzyme tended to improve the nutritive value of corn-soybean diet in broiler chicks (Shirmohammad and Mehri, 2011). The obtained results are in disagreement with Al-harthi et al. (2020) who found that phytase supplementation improved BWG in broiler chickens enhanced broiler body weight gain and performance (Scholey et al., 2018 and Broch et al., 2018).

BWG of broiler chicks fed 250 or $500 \mathrm{mg}$ optizyme with 1500 FTU phytase achieved the highest BWG than control groups. The interactions between phytase and optizyme (Table 2) showed that the groups $(\mathrm{O} \times \mathrm{P} 1), \quad(\mathrm{O} 1 \times \mathrm{P}),(\mathrm{O} 1 \times \mathrm{P} 1), \quad(\mathrm{O} 2 \times \mathrm{P}),(\mathrm{O} 2 \times \mathrm{P} 1)$ had higher $\mathrm{BWG}$ than control group $(.(\mathrm{O} \times \mathrm{P})$. Study conducted by Moss et al. (2017) showed that protease supplementation alone increased weight gains of poultry, but in combination with phytase decrease weight gain.

No significant effects due treatments at all on feed intake (Table 2). The obtained results are in agreement with Abudabos (2012) who found that at 10 day, no significant differences in FI were found due to enzyme supplementation.

No significant effects due treatments at all on FCR were detected. Similar trends were showed with Min et al. (2011) who showed that using enzyme mixture containing pectinase (provided by $200 \mathrm{~g} /$ tone feed) to diets of broilers contained lower $40 \mathrm{kcal} / \mathrm{kg}$ ME could not improve FCR. Rutherfurd et al. (2012) reported that no effect of phytase supplementation on feed efficiency of broilers fed low avPdiets.

In the present study phytase or optizyme or interaction have not been shown increase either on feed intake or feed conversion. However, some authors mentioned conflict results (Bradbury et al.; 2017 and Moss et al, 2017), that Phytase present in the feed ingredients themselves has been shown to increase daily feed consumption which proportionally increases body weight gain as well as the growth-rate of poultry. ElGhamry et al. (2005) found that phytase without or with multienzymes mixture improved growth and FCR significantly compared to their negative control. They also found that the combination of phytase plus multienzymes yield better results than phytase alone.

\section{Tibia characteristics:}

The results of tibia dry weigh, length (L), Diameter (D), weight length index (WLI), Ash \%, and phosphorus $\%$ as affected by treatments at 35 days ( from one day old to 5 weeks of age) are presented in Table 3. The results showed non significant $(\mathrm{P} \leq 0.05)$ differences due to optizyme addition for all Tibia characteristics, except of Ash \%, and Phosphorus \%. Birds fed to $250 \mathrm{mg} / \mathrm{kg}$ diet optizyme enzyme level had significant $(\mathrm{P} \leq 0.05)$ higher ash and phosphorus \% than those in $500 \mathrm{mg} / \mathrm{kg}$ diet optizyme enzyme. However, birds fed on $500 \mathrm{mg} / \mathrm{kg}$ diet optizyme enzyme level supplementation had significant $(\mathrm{P} \leq 0.05)$ lower ash \% than those control and $250 \mathrm{mg}$ optizyme enzyme level supplementation. Birds fed the control diets (free optizyme enzyme supplementation) had an intermediate values. Similar trends with enzymes that affected bone characteristics were reported. The addition of enzymes to the diet positively affects mineral absorption in the intestine (Thomas and Ravindran, 2010).

No significant $(\mathrm{P} \leq 0.05)$ differences for all tibia characteristics due to phytase addition were reported. The obtained results are in agreement with Rama Rao et al. (2014) who reported that phosphorus contents in the 
Table (2): Effect of treatments on performance response (g/bird) of broiler chickens.

\begin{tabular}{|c|c|c|c|c|}
\hline \multirow[t]{2}{*}{ Treatment } & \multicolumn{4}{|c|}{5 wks of age } \\
\hline & Final BW $(\mathrm{g})$ & $\mathrm{BWG}(\mathrm{g})$ & FI $(\mathrm{g})$ & FCR \\
\hline \multicolumn{5}{|c|}{ Optizyme levels (mg/kg) } \\
\hline $0(\mathrm{O})$ & $1664.08 \pm 55^{\mathrm{b}}$ & $1622.08 \pm 55^{b}$ & $2607.48 \pm 71$ & $1.61 \pm 0.04$ \\
\hline $250(\mathrm{O} 1)$ & $1697.77 \pm 45^{\mathrm{a}}$ & $1655.77 \pm 45^{\mathrm{a}}$ & $2721.09 \pm 71$ & $1.64 \pm 0.03$ \\
\hline $500(\mathrm{O} 2)$ & $1700.70 \pm 30^{\mathrm{a}}$ & $1658.70 \pm 30^{\mathrm{a}}$ & $2693.99 \pm 30$ & $1.62 \pm 0.02$ \\
\hline \multicolumn{5}{|c|}{ Phytase levels (FTU/kg) } \\
\hline $0(\mathrm{P})$ & $1693.68 \pm 37$ & $1651.68 \pm 37$ & $2676.21 \pm 53$ & $1.62 \pm 0.02$ \\
\hline $1500(\mathrm{P} 1)$ & $1681.35 \pm 35$ & $1639.35 \pm 35$ & $2672.16 \pm 29$ & $1.63 \pm 0.03$ \\
\hline \multicolumn{5}{|c|}{ Interactions } \\
\hline $\mathrm{O} \times \mathrm{P}$ & $1616.59 \pm 76^{c}$ & $1574.59 \pm 76^{b}$ & $2605.30 \pm 145$ & $1.65 \pm 0.04$ \\
\hline $\mathrm{O} \times \mathrm{P} 1$ & $1711.56 \pm 83^{\mathrm{a}}$ & $1669.56 \pm 83^{\mathrm{a}}$ & $2609.70 \pm 53$ & $1.56 \pm 0.07$ \\
\hline $\mathrm{O} 1 \times \mathrm{P}$ & $1727.32 \pm 74^{\mathrm{a}}$ & $1685.32 \pm 74^{\mathrm{a}}$ & $2707.30 \pm 88$ & $1.61 \pm 0.03$ \\
\hline $\mathrm{O} 1 \times \mathrm{P} 1$ & $1668.21 \pm 60^{\mathrm{b}}$ & $1626.21 \pm 60^{\mathrm{a}}$ & $2734.80 \pm 15$ & $1.68 \pm 0.05$ \\
\hline $\mathrm{O} 2 \times \mathrm{P}$ & $1737.14 \pm 27^{\mathrm{a}}$ & $1695.14 \pm 27^{\mathrm{a}}$ & $2716.00 \pm 14$ & $1.60 \pm 0.03$ \\
\hline $\mathrm{O} 2 \times \mathrm{P} 1$ & $1664.26 \pm 52^{\mathrm{b}}$ & $1622.26 \pm 52^{\mathrm{a}}$ & $2672.00 \pm 62$ & $1.65 \pm 0.04$ \\
\hline
\end{tabular}

${ }^{a-c}$ Means in the same columns with different superscript are significant different $(P \leq 0.05)$.

$B W=$ body weight., $B W G=$ body weight gain., FI=feed intake., $F C R=$ Feed conversion ratio.

Table (3): Effect of treatments on tibia characteristics of broiler chickens.

\begin{tabular}{|c|c|c|c|c|c|c|}
\hline \multirow[t]{2}{*}{ Treatment } & \multicolumn{6}{|c|}{ Tibia characteristics } \\
\hline & $\begin{array}{l}\text { Tibia dry weight } \\
(\mathrm{g})\end{array}$ & $\begin{array}{l}\text { Length } \\
(\mathrm{cm})\end{array}$ & $\begin{array}{l}\text { Diameter } \\
(\mathrm{cm})\end{array}$ & $\begin{array}{c}\text { WLI } \\
(\mathrm{mg} / \mathrm{mm})\end{array}$ & $\begin{array}{l}\text { Ash } \\
(\%)\end{array}$ & $\begin{array}{c}\text { Phosphorus } \\
(\%)\end{array}$ \\
\hline \multicolumn{7}{|c|}{ Optizyme levels (mg/kg) } \\
\hline $0(\mathrm{O})$ & $5.25 \pm 0.30$ & $8.83 \pm 0.22$ & $0.66 \pm 0.05$ & $59.45 \pm 3.29$ & $46.67 \pm 0.43^{\mathrm{a}}$ & $15.31 \pm 0.9^{\mathrm{ab}}$ \\
\hline $250(\mathrm{O} 1)$ & $5.20 \pm 0.15$ & $8.53 \pm .013$ & $0.63 \pm 0.04$ & $60.96 \pm 2.26$ & $46.98 \pm 0.92^{\mathrm{a}}$ & $18.34 \pm 0.6^{\mathrm{a}}$ \\
\hline $500(\mathrm{O} 2)$ & $5.90 \pm 0.27$ & $8.66 \pm 0.13$ & $0.70 \pm 0.04$ & $68.13 \pm 3.71$ & $43.91 \pm 0.67^{b}$ & $14.59 \pm 1^{\mathrm{b}}$ \\
\hline \multicolumn{7}{|c|}{ Phytase levels (FTU/kg) } \\
\hline $0(\mathrm{P})$ & $5.34 \pm 0.24$ & $8.61 \pm 0.10$ & $0.65 \pm 0.02$ & $62.02 \pm 3.13$ & $45.00 \pm 0.46$ & $17.41 \pm 0.95$ \\
\hline $1500(\mathrm{P} 1)$ & $5.56 \pm 0.19$ & $8.74 \pm 0.16$ & $0.67 \pm 0.04$ & $63.62 \pm 2.52$ & $46.71 \pm 0.83$ & $14.75 \pm 0.98$ \\
\hline \multicolumn{7}{|l|}{ Interactions } \\
\hline $\mathrm{O} \times \mathrm{P}$ & $4.89 \pm 0.43$ & $8.40 \pm 0.20^{\mathrm{b}}$ & $0.60 \pm 0.05$ & $59.95 \pm 3.17$ & $45.93 \pm 0.1^{b c}$ & $16.51 \pm 1^{\mathrm{ab}}$ \\
\hline $\mathrm{O} \times \mathrm{P} 1$ & $5.62 \pm 0.35$ & $9.26 \pm 0.14^{\mathrm{a}}$ & $0.73 \pm 0.08$ & $58.21 \pm 6.61$ & $47.41 \pm 0.6^{\mathrm{ab}}$ & $14.12 \pm 1^{\mathrm{b}}$ \\
\hline $\mathrm{O} 1 \times \mathrm{P}$ & $5.06 \pm 0.17$ & $8.70 \pm 0.15^{\mathrm{ab}}$ & $0.63 \pm 0.03$ & $58.16 \pm 2.88$ & $45.27 \pm 0.4^{b c}$ & $19.49 \pm 0.6^{\mathrm{a}}$ \\
\hline $\mathrm{O} 1 \times \mathrm{P} 1$ & $5.34 \pm 0.26$ & $8.36 \pm 0.18^{b}$ & $0.63 \pm 0.08$ & $63.87 \pm 3.38$ & $48.69 \pm 1^{\mathrm{a}}$ & $17.19 \pm 0.5^{\mathrm{ab}}$ \\
\hline $\mathrm{O} 2 \times \mathrm{P}$ & $6.09 \pm 0.32$ & $8.73 \pm 0.21^{\mathrm{ab}}$ & $0.73 \pm 0.03$ & $69.76 \pm 7.55$ & $43.79 \pm 1^{\mathrm{c}}$ & $16.25 \pm 2 \mathrm{a}^{\mathrm{b}}$ \\
\hline $\mathrm{O} 2 \times \mathrm{P} 1$ & $5.71 \pm 0.48$ & $8.60 \pm 0.20^{\mathrm{b}}$ & $0.66 \pm 0.08$ & $66.39 \pm 3.30$ & $44.02 \pm 1^{\mathrm{c}}$ & $12.93 \pm 2^{\mathrm{b}}$ \\
\hline
\end{tabular}

${ }^{a-c}$ Means in the same columns with different superscript are significant different $(P \leq 0.05)$.

WLI= Weight length Index $(\mathrm{mg} / \mathrm{mm})$. Tibia calcium \% was avoid.

bones of broilers were not affected by supplementation of NSP-hydrolysing enzymes to guar meal- based diets. Walk et al. (2013) reported that super doses of phytase supplementation in low-P diet in 0- to 21dayold broiler did not alter tibia ash percentage..

The present results concerning with phytase addition are in disagreement with Scholey et al. (2018), who reported that phytase had bone mineralization in broiler chickens.. Previous researchers also reported the efficacy of phytase on bone mineralization in poultry (Bradbury et al., 2017. The benefit of phytase supplementation was greater in younger than older chicken (Li et al., 2018).

Manobhavan et al. (2015) who found that super doses of phytase (at $2500 \mathrm{FTU}$ and $5000 \mathrm{FTU} / \mathrm{kg}$ ) on low-phosphorus diet improved bone minerals such as calcium $(\mathrm{Ca})$ and phosphorus $(\mathrm{P})$.

The interactions between optizymes and phytase had significant $(\mathrm{P}<0.05)$ effects on length, ash\% and phosphorus\%. The birds in group (O1XP1) had the highest value in ash\%. However, group (O1X P) had the highest value in tibia phosphorus $\%$. 
Length was significantly $(\mathrm{P} \leq 0.05)$ the highest in birds reared in group (OXP1) than others groups. No published reviews are available on the interaction between optizyme and phytase enzymes supplementation in broiler feeds.

\section{Calcium retention efficiency:}

The data of Table (4) revealed non-significant $(\mathrm{P} \leq 0.05)$ differences due to the optizyme enzyme for all calcium retention efficiency traits, except of Ca excreta \%. Birds fed on $(\mathrm{O}) \mathrm{mg} / \mathrm{kg}$ diet optizyme enzyme level had significant $(\mathrm{P} \leq 0.05)$ the lowest Ca excreta \% compared to $250 \mathrm{mg} / \mathrm{kg}$ and $500 \mathrm{mg} / \mathrm{kg}$ optizyme.

Concerning with Phytase enzyme, the results showed no significant $(\mathrm{P} \leq 0.05)$ differences for calcium retention efficiency. Ca excreta \% was significantly $(\mathrm{P} \leq 0.05)$ the lowest in birds reared in groups $(\mathrm{O} \times \mathrm{P})$ then $\left(\mathrm{O} \times \mathrm{P}_{1}\right)$ compared to others groups. Englmaierová et al. (2017) reported non-significant increase in ileal digestibility of $\mathrm{Ca}$ due to phytase supplementation to the diets. Kiarie et al. (2014) reported that the addition of enzymes to wheat-based diets did not affect calcium retention in broilers.

Reversely, the obtained results are in disagreement with Moss et al. (2018), who reported an improve in illeal digestibility performance of calcium, in broiler chicken diets. Mushtaq et al. (2009) found that the enzyme significant increased retention of excreta calcium, compared to without enzyme. Diet supplemented with enzyme had a positive effect on nutrient absorption of birds fed diets containing sunflower meal (SFM). Pure enzyme supplementation increased the retention of calcium in birds, which helps in better utilization of alternate feed ingredients (Ramesh and Chandrasekaran, 2011).

\section{Phosphorus retention efficiency:}

The data of Table (5) revealed significant $(\mathrm{P} \leq 0.05)$ differences due to the optizyme enzyme for $\mathrm{P} \%$, $\mathrm{P} /$ feed and $\mathrm{P}$ retention\%. .Birds fed on $500 \mathrm{mg} / \mathrm{kg}$ diet optizyme enzyme level supplementation had a significant $(\mathrm{P} \leq 0.05)$ the lowest $\mathrm{P} \%$ and $\mathrm{P} /$ feed compared to those in control group (0) $\mathrm{mg} / \mathrm{kg}$ and $250 \mathrm{mg} / \mathrm{kg}$ diet optizyme enzyme level supplementation. Birds fed on $250 \mathrm{mg} / \mathrm{kg}$ diet optizyme enzyme level had significant $(\mathrm{P} \leq 0.05)$ the highest $\mathrm{P}$ retention efficiency\% than those in $250 \mathrm{mg} / \mathrm{kg}$ diet optizyme enzyme level.

Table (4): Effect of treatments on calcium retention efficiency of broiler chickens.

\begin{tabular}{|c|c|c|c|c|c|c|c|}
\hline \multirow[t]{2}{*}{ Treatment } & \multicolumn{7}{|c|}{ Calcium retention efficiency } \\
\hline & Dry feed & $\begin{array}{l}\mathrm{Ca} \\
(\%)\end{array}$ & $\mathrm{Ca} /$ feed & $\begin{array}{l}\text { Dry } \\
\text { Excreta }\end{array}$ & $\begin{array}{c}\text { Ca excreta } \\
(\%)\end{array}$ & $\mathrm{Ca} /$ excreta & $\begin{array}{c}\text { Ca retention } \\
\%\end{array}$ \\
\hline \multicolumn{8}{|c|}{ Optizyme levels (mg) } \\
\hline $0(\mathrm{O})$ & $135.56 \pm 13$ & $0.93 \pm 0.00$ & $1.26 \pm 0.12$ & $22.13 \pm 1.89$ & $1.82 \pm 0.18^{\mathrm{b}}$ & $0.39 \pm 0.03$ & $69.04 \pm 3.82$ \\
\hline $250(\mathrm{O} 1)$ & $150.83 \pm 13$ & $0.93 \pm 0.00$ & $1.40 \pm 0.12$ & $18.11 \pm 1.90$ & $2.70 \pm 0.23^{\mathrm{a}}$ & $0.47 \pm 0.04$ & $66.42 \pm 2.05$ \\
\hline $500(\mathrm{O} 2)$ & $125.88 \pm 9$ & $0.93 \pm 0.00$ & $1.17 \pm 0.08$ & $18.44 \pm 2.24$ & $2.76 \pm 0.26^{\mathrm{a}}$ & $0.49 \pm 0.06$ & $58.11 \pm 4.24$ \\
\hline \multicolumn{8}{|c|}{ Phytase levels (FTU) } \\
\hline $0(\mathrm{P})$ & $131.76 \pm 10$ & $0.93 \pm 0.00$ & $1.22 \pm 0.09$ & $18.99 \pm 1.84$ & $2.41 \pm 0.25$ & $0.43 \pm 0.04$ & $64.75 \pm 3.31$ \\
\hline $1500(\mathrm{P} 1)$ & $143.08 \pm 10$ & $0.93 \pm 0.00$ & $1.33 \pm 0.09$ & $20.13 \pm 1.56$ & $2.45 \pm 0.22$ & $0.47 \pm 0.03$ & $64.66 \pm 3.04$ \\
\hline \multicolumn{8}{|l|}{ Interactions } \\
\hline $\mathrm{O} \times \mathrm{P}$ & $129.36 \pm 23$ & $0.93 \pm 0.00$ & $1.20 \pm 0.21$ & $22.16 \pm 3.17$ & $1.71 \pm 0.21^{\mathrm{b}}$ & $0.37 \pm 0.06$ & $69.16 \pm 6.05$ \\
\hline $\mathrm{O} \times \mathrm{P} 1$ & $141.76 \pm 19$ & $0.93 \pm 0.00$ & $1.31 \pm 0.18$ & $22.11 \pm 2.81$ & $1.94 \pm 0.34^{\mathrm{b}}$ & $0.41 \pm 0.02$ & $68.70 \pm 6.04$ \\
\hline $\mathrm{O} 1 \times \mathrm{P}$ & $146.66 \pm 14$ & $0.93 \pm 0.00$ & $1.36 \pm 0.13$ & $19.00 \pm 3.42$ & $2.34 \pm 0.16^{\mathrm{ab}}$ & $0.43 \pm 0.07$ & $68.38 \pm 3.21$ \\
\hline $\mathrm{O} 1 \times \mathrm{P} 1$ & $154.99 \pm 26$ & $0.93 \pm 0.00$ & $1.44 \pm 0.24$ & $17.22 \pm 2.37$ & $3.06 \pm 0.34^{\mathrm{a}}$ & $0.51 \pm 0.04$ & $64.58 \pm 2.35$ \\
\hline $\mathrm{O} 2 \times \mathrm{P}$ & $119.26 \pm 18$ & $0.93 \pm 0.00$ & $1.10 \pm 0.17$ & $15.83 \pm 3.02$ & $3.18 \pm 0.37^{\mathrm{a}}$ & $0.49 \pm 0.09$ & $55.45 \pm 5.52$ \\
\hline $\mathrm{O} 2 \times \mathrm{P} 1$ & $132.49 \pm 5$ & $0.93 \pm 0.00$ & $1.23 \pm 0.05$ & $21.05 \pm 3.04$ & $2.35 \pm 0.15^{\mathrm{ab}}$ & $0.50 \pm 0.09$ & $59.34 \pm 7.38$ \\
\hline
\end{tabular}

Concerning with Phytase enzyme, the results showed no significant $(\mathrm{P} \leq 0.05)$ differences on phosphorus retention efficiency traits. The obtained results are in disagreement with Moss et al. (2018) and Kim et al., (2017) who mentioned that phytase improved the p retention in broiler chickens. Ghosh et al. ( 2016) found that supplementation of phytase in the diets of laying hens has been shown to improve the availability of phytate P. Manobhavan et al. (2016) found that super doses of phytase (at $2500 \mathrm{FTU}$ and $5000 \mathrm{FTU} / \mathrm{kg}$ ) on low-phosphorus diet improved ileal digestibility phosphorus. El-Sherbiny et al. (2010) reported that phytase 
when reduced in broiler diets increased dietary $\mathrm{P}$ utilization and $\mathrm{P}$ excretion in broiler chickens. In addition, Motawe et al. (2012) reported that phytase supplementation significantly $(\mathrm{P}<0.05)$ decreased $\mathrm{P}$ excretion

Concerning with the interactions, there were significant effect on $\mathrm{P} \%$ in feed intake and $\mathrm{P}$ phosphorus retention efficiency. $\mathrm{P} \%$ was significant $(\mathrm{P} \leq 0.05)$ lowest in birds reared in group $\left(\mathrm{O}_{2} \times \mathrm{P}_{1}\right)$ compared to others groups. However, birds in the group $\mathrm{O} \times \mathrm{P}$ had the highest $\mathrm{P} \%$ compared to others groups.

Table (5): Effect of treatments on phosphorus retention efficiency of broiler chickens.

\begin{tabular}{|c|c|c|c|c|c|c|c|}
\hline \multirow[t]{2}{*}{ Treatment } & \multicolumn{7}{|c|}{ Phosphorus retention efficiency\% } \\
\hline & Dry feed & $\begin{array}{c}\mathrm{P} \\
(\%)\end{array}$ & $\mathrm{P} /$ feed & $\begin{array}{c}\text { Dry } \\
\text { Excreta }\end{array}$ & $\begin{array}{c}\text { P excreta } \\
(\%)\end{array}$ & P/excreta & $\begin{array}{c}\text { P retention } \\
\%\end{array}$ \\
\hline \multicolumn{8}{|c|}{ Optizyme levels (mg) } \\
\hline $0(\mathrm{O})$ & $135.56 \pm 13$ & $0.84 \pm 0.01^{\mathrm{a}}$ & $1.13 \pm 0.11^{\mathrm{a}}$ & $61.98 \pm 5$ & $0.65 \pm 0.00$ & $0.40 \pm 0.03$ & $64.17 \pm 1^{\mathrm{ab}}$ \\
\hline $250(\mathrm{O} 1)$ & $150.83 \pm 13$ & $0.77 \pm 0.01^{\mathrm{b}}$ & $1.17 \pm 0.10^{\mathrm{a}}$ & $50.71 \pm 5$ & $0.65 \pm 0.00$ & $0.32 \pm 0.03$ & $71.60 \pm 2^{\mathrm{a}}$ \\
\hline $500(\mathrm{O} 2)$ & $125.88 \pm 9$ & $0.65 \pm 0.03^{\mathrm{c}}$ & $0.82 \pm 0.06^{\mathrm{b}}$ & $51.64 \pm 6$ & $0.65 \pm 0.00$ & $0.33 \pm 0.04$ & $59.10 \pm 4^{\mathrm{b}}$ \\
\hline \multicolumn{8}{|c|}{ Phytase levels (FTU) } \\
\hline $0(\mathrm{P})$ & $131.76 \pm 10$ & $0.79 \pm 0.02$ & $1.05 \pm 0.09$ & $53.19 \pm 5$ & $0.65 \pm 0.00$ & $0.34 \pm 0.03$ & $67.07 \pm 1$ \\
\hline $\begin{array}{l}1500(\mathrm{P} 1) \\
\text { Interactions }\end{array}$ & $143.08 \pm 10$ & $0.71 \pm 0.03$ & $1.03 \pm 0.09$ & $56.36 \pm 4$ & $0.65 \pm 0.00$ & $0.36 \pm 0.03$ & $62.84 \pm 3$ \\
\hline $\mathrm{O} \times \mathrm{P}$ & $129.36 \pm 23$ & $0.86 \pm 0.00^{\mathrm{a}}$ & $1.11 \pm 0.20$ & $62.05 \pm 8$ & $0.65 \pm 0.00$ & $0.40 \pm 0.05$ & $63.22 \pm 2^{\mathrm{ab}}$ \\
\hline $\mathrm{O} \times \mathrm{P} 1$ & $141.76 \pm 19$ & $0.82 \pm 0.00^{\mathrm{b}}$ & $1.16 \pm 0.16$ & $61.91 \pm 7$ & $0.65 \pm 0.00$ & $0.40 \pm 0.05$ & $65.13 \pm 3^{\mathrm{a}}$ \\
\hline $\mathrm{O} 1 \times \mathrm{P}$ & $146.66 \pm 14$ & $0.81 \pm 0.00^{c}$ & $1.19 \pm 0.12$ & $53.20 \pm 9$ & $0.65 \pm 0.00$ & $0.34 \pm 0.06$ & $71.15 \pm 4^{\mathrm{a}}$ \\
\hline $\mathrm{O} 1 \times \mathrm{P} 1$ & $154.99 \pm 26$ & $0.74 \pm 0.00^{\mathrm{d}}$ & $1.15 \pm 0.19$ & $48.22 \pm 6$ & $0.65 \pm 0.00$ & $0.31 \pm 0.04$ & $72.05 \pm 4^{\mathrm{a}}$ \\
\hline $\mathrm{O} 2 \times \mathrm{P}$ & $119.26 \pm 18$ & $0.72 \pm 0.00^{\mathrm{e}}$ & $0.85 \pm 0.13$ & $44.33 \pm 8$ & $0.65 \pm 0.00$ & $0.28 \pm 0.05$ & $66.84 \pm 1^{\mathrm{a}}$ \\
\hline $\mathrm{O} 2 \times \mathrm{P} 1$ & $132.49 \pm 5$ & $0.59 \pm 0.00^{\mathrm{f}}$ & $0.78 \pm 0.03$ & $58.95 \pm 8$ & $0.78 \pm 0.00$ & $0.38 \pm 0.05$ & $51.36 \pm 5^{\mathrm{b}}$ \\
\hline
\end{tabular}

Phosphorus retention efficiency was significantly $(\mathrm{P} \leq 0.05)$ the lowest in birds reared in groups $\left(\mathrm{O}_{2} \times \mathrm{P}_{1}\right)$ compared to others groups.

\section{CONCLUSION}

Supplementation of commercial enzymes can increase the nutritive value of feed ingredients and diets as well as allow greater flexibility in diet formulation. It has also a potential effect on mitigation of the environmental pollution by reducing the excretion of some elements such as nitrogen and phosphorus in poultry manure. Based on the results of the present study, it can be concluded that the level of 250 or 500 $\mathrm{mg} / \mathrm{kg}$ diet multienzyme optizyme and $1500 \mathrm{FTU} / \mathrm{kg}$ diet phytase is effective for increasing absorption and bioavailability of phosphorus, which could decrease excretion of phosphorous and, therefore, environmental pollution. In addition, feeding broilers with those treated feeds might improve body weight gain.

\section{REFERENCES}

AOAC (1990).Association of Official Analytical Chemists.Official methods of analysis. Assoc Anal Chem.

Abd El-Hack, M. E., M., Alagawany, V., R., Laudadio, Demauro and V. Tufarelli (2017). Dietary inclusion of raw faba bean instead of soybean meal and enzyme supplementation in laying hens: Effect on performance and egg quality, Saudi J. Biol. Sci., 24, 276-285,

Abudabos, M. A., (2012).Effect of enzyme supplementation to normal and low density broiler diets based on corn- soybean meal. Asian .J .Anim. Vet. Adv., 7:139-148. 


\section{Metwally et al.}

Al-Harthi, M. A., Y. A., Attia, A. S., El-Shafey and M. F. Elgandy,(2020). Impact of phytase on improving the utilisation of pelleted broiler diets containing olive by-products. Italian Journal of Animal Science, 19(1), 310-318.

Attia, Y. A., M. A., Al-Harthi and A. S. El-Shafey (2020). Influence of Different Time and Frequency of Multienzyme Application on the Efficiency of Broiler Chicken Rearing and Some Selected Metabolic Indicators. Animals, 10(3), 450.

Bradbury, E.J., S.J., Wilkinson, G.M., Cronin, P., Thomson, C.L., Walk and A.J. Cowieson (2017). Evaluation of the effect of a highly soluble calcium source in broiler diets supplemented with phytase on performance, nutrient digestibility, foot ash, mobility and leg weakness. Anim Prod Sci., 57(10), 20162026.

Broch, J., R. V., Nunes, C., Eyng, G. M., Pesti, C., de Souza, G. G., Sangalli and L. Teixeira (2018). Effect of dietary phytase superdosing on broiler performance. Anim Feed SciTechnoldoi: 10.1016/j.anifeedsci.2018.06.001.

Duncan D. B.(1955). Multiple range and multiple "F" test. Biometrics 11:1- 42.

El-Ghamry AA, MA, Al-Harthiand and Y.A. Attia (2005). Possibility to improve rice polishing utilisation in broiler diets by enzymes or dietary formulation based on digestible amino acids. Arch Geflugelk 69, 4956. ArchivTierzucht 57 (2014) 34, 1-11.

El-Sherbiny, A. E., H. M. A. Hassan, M. O. Abd-Elsamee, A. Samy and M. A. Mohamed (2010). Performance, bone parameters and phosphorus excretion of broilers fed low phosphorus diets supplemented with phytase from 23 to 40 days of age. Int. J. Poult. Sci., 9:972-977.

Englmaierová, M., M., Skřivan, E., Skřivanová and L. Čermák (2017).Limestone particle size and Aspergillusniger phytase in the diet of older hens. Italian Journal of Animal Science, 16(4), 608-615.

Enshasy, H. E., D. J., Dailin, N. H., AbdManas, N. I. W., Azlee, J., Eyahmalay, S. A., Yahaya and D. Sukmawati (2018). Current and future applications of phytases in poultry industry: a Critical Review. Journal of Advances in VetBio Science and Techniques, 3(3), 65-74.

Ghosh, A., G. P., Mandal, A., Roy and A. K. Patra (2016).Effects of supplementation of manganese with or without phytase on growth performance, carcass traits, muscle and tibia composition, and immunity in broiler chickens. Livestock Science, 191, 80-85.

Graña, A. L., F. D. C., G. R., Tavernari, L. F. T., Lelis, H. S., Albino, Rostagno and P. C. Gomes (2013). Evaluation of nutrient excretion and retention in broilers submitted to different nutritional strategies. Brazilian Journal of Poult., Sci., 15(2), 161-168.

Kalantar, M, F. Khajali and A. Yaghobfar (2015). Different dietary source of non-starch polysaccharides supplemented with enzymes affected growth and carcass traits, blood parameters and gut physicochemical properties of broilers. Global J. Anim. Sci. Res., 3: 412-418.

Kiarie, E.; L. F. Romero and V. Ravindran (2014). Growth performance, nutrient utilization, and digest characteristics in broiler chickens fed corn or wheat diets without or with supplemental xylanase. Poultry Science, Savoy, v. 93, n. 10, p. 1186-1196.

Kim, J.H., G.P., Han, J.E., Shin and D.Y. Kil (2017).Effect of dietary calcium concentrations in phytasecontaining diets on growth performance, bone mineralization, litter quality, and footpad dermatitis score in broiler chickens.Anim Feed Sci. Technol, 229, 13-18. doi: 10.1016/j.anifeedsci.2017.04.008.

Li, W., R., Angel, S. W., Kim, E., Jiménez-Moreno, M., Proszkowiec-Weglarz and P.W. Plumstead (2018).Impacts of age and calcium on Phytase efficacy in broiler chickens. Anim Feed SciTechnol, 238, 9-17. doi: 10.1016/j.anifeedsci.2018.01.021.

Manobhavan, M., A. V. Elangovan, M. D. Sridhar, Shet, S. Ajith, D. T. Pal and N. K. S. Gowda (2016). Effect of super dosing of phytase on growth performance, ileal digestibility and bone characteristics in broilers fed corn-soya-based diets. Journal of animal physiology and animal nutrition, 100(1), 93-100.

Manobhavan, M., M., Sridhar, S., Ajith, D., Shet, D. T., Pal, N. K. S., Gowda and A. V. Elangovan (2015).Efficacy of fungal phytase on growth performance and bone mineralization in broiler chicken. Animal Nutrition and Feed Technology, 15(1), 129-136. 
Min, Y. N., F. Z., Liu, A., Hancock, C., Coto, C., A., Lu, Karimi, F., Yan and P. Waldroup (2011) Evaluation of Rovabio in normal and reduced-nutrient corn-soybean meal and Distillers Dried Grains with Solubles diets for broilers. Int. J. Poult. Sci., 10: 786-795.

Moss, A.F., P.V., Chrystal, Y., Dersjant-Li, P.H., Selle and S.Y. Liu (2018).Responses in digestibilities of macro-minerals, trace minerals and amino acids generated by exogenous phytase and xylanase in canola meal diets offered to broiler chickens. Anim. Feed Sci. Technol., 240, 22-30.

Moss, A.F., P.V., Chrystal, H.H., Truong, S.Y., Liu and P H. Selle (2017).Effects of phytase inclusions in diets containing ground wheat or $12.5 \%$ whole wheat (pre-and post-pellet) and phytase and protease additions, individually and in combination, to diets containing $12.5 \%$ pre-pellet whole wheat on the performance of broiler chickens. Anim. Feed Sci. Technol., 234, 139-150.

Motawe, H. F. A., T. M. EL-Afifi, H. M. A. Hassan and Y. A. Attia (2012). Addition of phytase to broiler diets contained different lysine levels. Egypt. Poult. Sci. Vol (32) (I): 117-130.

Mushtaq, T; M. Sarwara, G. Ahmad, MA.Mirza, T. Ahmad, MMH. Mushtaq and Z. Kamran (2009). Influence of sunflower meal based diets supplemented with exogenous enzyme and digestible lysine on performance, digestibility and carcass response of broiler chickens. Anim. Feed Sci. Technol., 149: 275286.

NRC (1994). Nutrient Requirements of Poultry.9th rev. ed. Natl. Acad. Press, Washington, DC, USA.

RamaRao, S. V., B. Prakash,M. V.L. N.Raju,A. K.Panda and O. K. Murthy (2014). Effect of Supplementing Non-Starch Polysaccharide Hydrolyzing Enzymes in Guar Meal Based Diets on Performance, Carcass Variables and Bone Mineralization in Vanaraja Chicken." Animal Feed Science and Technology 188: 85-91.

Ramesh, J., and Chandrasekaran (2011).effect of exogenous enzyme supplementation on performance of cockerels, Tamil Nadu Journal of Veterinary and Animal Sciences, 7(1): 29-34.

Rezaeipour, V., O. A. Nejad and H. Y. Miri (2014). Growth performance, blood metabolites and jejunum morphology of broiler chickens fed diets containing earthworm (Eiseniafoetida) meal as a source of protein. International Journal of Advanced Biological and Biomedical Research, 2(8), 2483-2494.

Rutherfurd, S. M., T. K. Chung, D. V. Thomas, M. L. Zou and P. J. Moughan (2012). Effect of a novel phytase on growth performance, apparent metabolizable energy, and the availability of minerals and amino acids in a low-phosphorus corn-soybean meal diet for broilers. Poult. Sci., 91:1118-1127.

SAS (2009). User’s Guide. Version, 9.2, 2002-2009, SAS institute Inc., Cary, NC, USA.

Scholey, D.V., N.K., Morgan, A., Riemensperger, R., Hardy and E.J Burton (2018).Effect of supplementation of phytase to diets low in inorganic phosphorus on growth performance and mineralization of broilers. Poult. Sci., 97(7), 2435-2440.

Shirmohammad, F. and M. Mehri (2011).Effects of dietary supplementation of multi-enzyme complex on the energy utilization in rooster and performance of broiler chicks. Afr. J. Biotechnol., 10: 7541-7547.

Thomas, D. V. and V. Ravindran (2010). "Mineral Retention in Young Broiler Chicks Fed Diets Based on Wheat, Sorghum or Maize.” Asian-Australasian Journal of Animal Sciences 23: 68-73.

Walk, C. L., M. R. Bedford, T. T. Santos, D. Paiva, J. R. Bradley, H. Wladecki, C. Honaker and A. P. McElroy (2013). Extra-phos- phoric effects of superdoses of a novel microbial phytase. Poult. Sci.,92:719-725.

Zeng, Q; X. Huang, Y. Luo, X. Ding, S. Bai, J. Wang, Y. Xuan, Z. Su, Y. Liu and K. Zhang (2015). Effects of a multi-enzyme complex on growth performance, nutrient utilization and bone mineralization of meat duck. J. Anim. Sci. Biotechnol., 6: 12. 


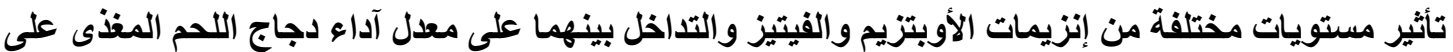

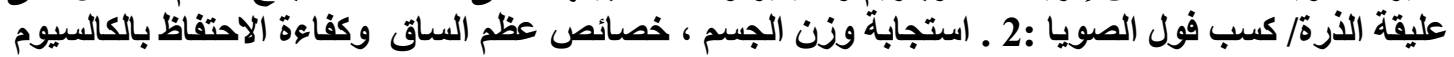

محمد متولى أحمد1 ، محمد فرغلى علم الدين1 ، زينهم شيخون إسماعيل22 ، محمد السيد غنيم3 و إيناس أحمد محمد4

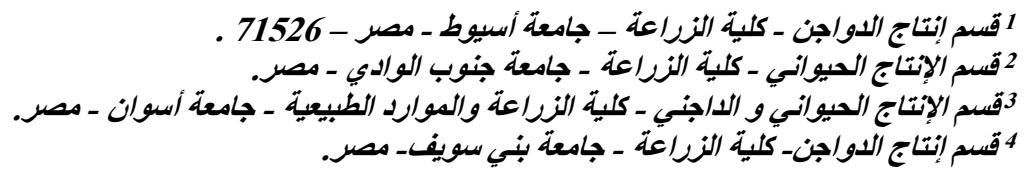

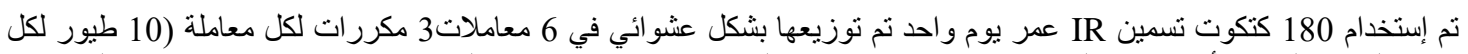

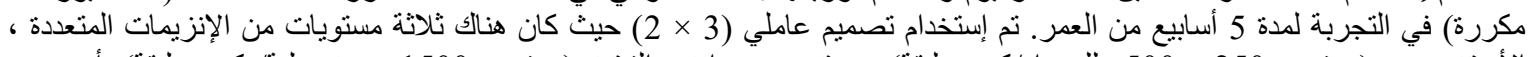

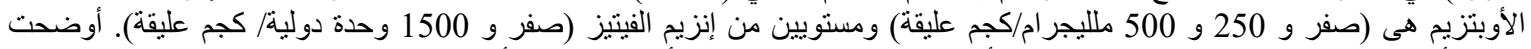

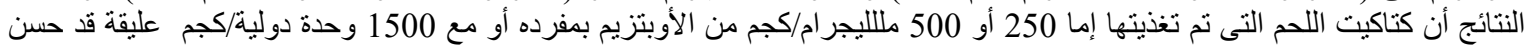

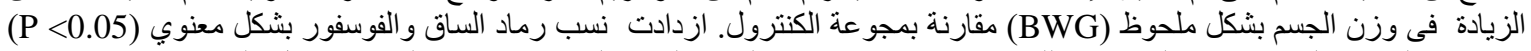

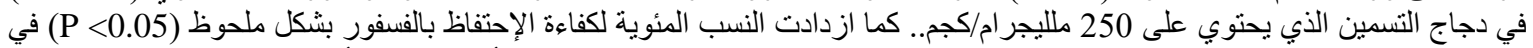

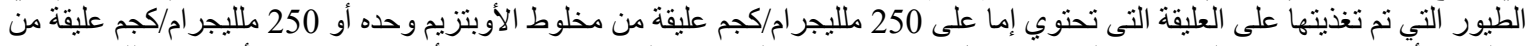

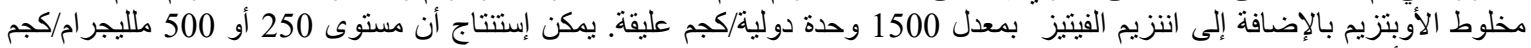

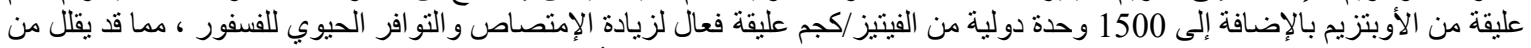

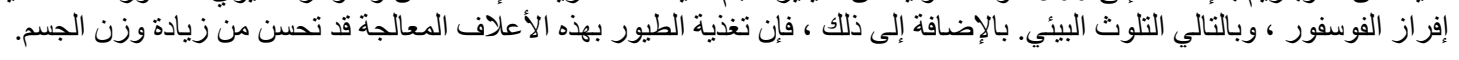

